Review

\title{
Sustainable Agricultural Mechanization for Smallholders: What Is It and How Can We Implement It?
}

\author{
Brian Sims ${ }^{1, *}$ and Josef Kienzle ${ }^{2}$ \\ 13 Bourneside, Bedford MK41 7EG, UK \\ 2 Plant Production and Protection Division, FAO, Viale delle Termi di Caracalla, Rome 00153, Italy; \\ Josef.Kienzle@fao.org \\ * Correspondence: BrianGSims@aol.com; Tel.: +44-1234-271-699
}

Academic Editors: Jacopo Bacenetti, Ester Foppa Pedretti and Domenico Pessina Received: 26 April 2017; Accepted: 7 June 2017; Published: 10 June 2017

\begin{abstract}
Smallholder farmers are the main producers of the world's food and they will have to increase production by up to 100 percent by 2050 to feed the growing population. This must be achieved while preserving natural resources and that is why sustainable agricultural mechanization (SAM) will be fundamental to the process. SAM is climate-smart and environmentally benign and essentially means no-till conservation agriculture, which requires specific mechanization inputs. Principally, these are seeders and planters capable of penetrating soil surface vegetative cover to deposit seed and fertilizer at the required depth and spacing; and equipment for management of cover crops and weeds. Mechanization is required not only for crop production, but also for processing and along the entire value chain. Mechanization inputs are usually expensive and so specialist service provision will be the indicated way forward. This will need collaboration from both the private and public sectors and will involve public-private partnerships to be developed in one form or another. Given the poor track record of public sector mechanization provision, the delivery of SAM should be firmly in the hands of the private sector that should be committed to SAM principles or otherwise be incentivized to the concept through smart subsidies. Improved information flows via smallholder farmer-friendly innovation platforms; and continuing development and testing of SAM technologies via regional centres of excellence will both be required - especially for sub-Saharan Africa.
\end{abstract}

Keywords: climate smart agriculture; environmental protection; mechanization service delivery; public-private partnerships; knowledge creation and dissemination; agricultural transformation

\section{Introduction}

The world is facing a crisis originated by a three-pronged attack which threatens the well-being of vast numbers of the planet's people. The crisis—some call it a "perfect storm"—has its origins in the convergence of population growth, natural resource degradation and the impacts of climate change.

The population of the world currently stands at 7.5 billion and is set to rise to around 10 billion by 2050 after that it will continue to rise and may exceed 12 billion by the end of the century [1]. These global figures mask regional variations and it seems that Asia (especially south Asia) and Africa will be home to the vast majority of the global population as their rates of growth are highest. Howard Buffet [2] estimates that the population of Africa is projected to increase from 1.1 billion today to at least 2.4 billion by 2050; while the Asian population will rise from the present 4.5 billion to 5.3 billion over the same time period [3].

The unsustainable advance of the global economy, which seeks to continue to grow year-on-year with a finite natural resource base, means that natural resource capital is everywhere being depleted. 
Although smallholder farmers are not the main culprits in provoking the widespread global destruction of forests, they are certainly responsible, at least in part, for the degradation of soil, water and woodland resources at the local level. It has been found [4] that globally human-induced degradation of agricultural soils is widespread and varies from light to extreme. It is calculated that we may be losing more than 9 billion hectares of arable land each year through erosion; in Africa it is estimated that 22 percent of productive land is affected by some form of degradation [5]. The term "soil degradation" covers a multiplicity of problems including [5]: loss of organic matter and nutrients; desertification; soil sealing; erosion by wind and water; decline in biodiversity; compaction and; salinization. Additionally, soils can be degraded through contamination resulting from human activities such as mining and road construction, and hydro-geological events such as landslides; frequently several threats may occur simultaneously and so the problems can be multiplied if they are not countered at an early stage. Worldwide agriculture accounts for 70 percent of water extraction (three times more than 50 years ago) [6] and today it is estimated that 40 percent of the world's rural population lives in water-scarce catchments. Competing demands from industry and the growing urban population are exacerbating an already critical situation.

The fifth assessment report (AR5) of the Intergovernmental Panel on Climate Change (IPCC) leaves us in no doubt that the climate changes that are now upon us are mainly due to anthropogenic emissions of greenhouse gasses (GHGs) [7]. The emissions from agriculture, forestry and other land use (AFOLU) now account for 20-22 percent of global $\mathrm{CO}_{2}$ equivalent GHG emissions (which total around 45 gigatonnes $\mathrm{CO}_{2} \mathrm{eq} /$ year). If emissions for primary production (especially from diesel fuel) and agricultural value chain operations are included, then the AFOLU GHG emissions increase by a further 4.3 gigatonnes $\mathrm{CO}_{2}$ eq/year [8].

GHG emissions result in global warming and we are now in a desperate race to confine global temperate rise to $2 \mathrm{C}$ above pre industrial revolution levels [9]. A warmer atmosphere has more energy and so will result in more extreme weather events. The IPCC has concluded that the Earth can expect more of what we are becoming used to in terms of the increased violence and frequency of such extreme events, including hurricanes, tropical storms, flooding, droughts, heatwaves and wildfires. The corresponding impacts on agricultural production will be huge and widespread from low to high latitudes [10].

Given the importance of family farms for feeding the planet's growing human population, this paper focuses on the issues surrounding sustainable mechanization for this sector. However we include consideration of the sustainable mechanization needs of larger scale farms in Section 2 (Mechanization of conservation agriculture). There are over 500 million family farms in the world and they occupy between 70 and 80 percent of farm land [11]. It is estimated that family farms produce about 80 percent of the world's food in value terms and so it is vital that they are not only supported but supported with technology (especially high quality inputs, including mechanization) that is compatible with sustainable production intensification. Such support should lead to a transformation process that will allow subsistence-oriented smallholders to develop into more market-oriented farmers. In our view this is a principal route to lead smallholders out of poverty through providing training, means and technologies along the value chain for reducing drudgery and increasing labour and land productivity in a sustainable way.

The mechanization of agriculture requires energy and this comes from farm power sources. In large scale agriculture the predominant farm power source is the diesel engine installed in tractors, combines, other self-propelled machines and stationary units where electric motors also play an important role. In the developing world, engine power is generally on the increase as low-cost tractors and other engine-powered technologies become increasingly available, especially from India and China. The use of draught animals for farm power is still important in many developing countries. Although there is a clear trend for animals to be replaced by engine power, this will take some time to achieve, even in rapidly developing countries such as India and China [12]. The Indian tractor manufacturing industry is currently the largest in the world, producing one third of global tractor 
production [13]. On the other hand, China claims to be the world's leading manufacturer of agricultural machinery in its widest sense, including tractors (both two-wheeled and four-wheeled), implements, other self-propelled machines, pumps and machinery for agricultural product processing along the output value chain [14]. There is a similar trend in Latin America where draught animal power has now declined to constitute about 25 percent of the power source for family farms. In sub-Saharan Africa (SSA) the use of draught animals is still important in many regions, but is constrained by the presence of the tsetse fly (Glossina spp.), the vector of trypanosomiasis, regionally in SSA, draught animal power contributes up to 25 percent of farm power [15].

It is still the case, however that human muscles are an extremely important source of farm power throughout the developing world, and especially in SSA where even today humans supply 65 percent of farm power. This constitutes a major limitation for increased land and labour productivity; it impacts heavily on the timeliness of farm operations and is a major source of drudgery. So much so that the African Union has proclaimed that the hand-hoe should be "consigned to the museum" by 2035 [16].

Given the situation that has been described above, we can see that low land and labour productivity can be the direct consequence of a lack of access to, and application of, key production inputs, including mechanization. There is a pressing need to increase global food production to feed the growing, and increasingly urban, global population. FAO [11] estimates that agricultural production globally must increase by 70 percent by 2050, and by 100 percent in developing countries, and so "business as usual" is really not an option if we are to avoid widespread food shortages.

At the same time, we are seeing a continuing degradation of the planet's natural resource base. It is, of course, this natural resource base-our natural capital— that provides the environment for agricultural production. Equally important in this sense are soil and water resources which are prone to abuse from conventional agricultural practices which involve intensive and excessive soil tillage. This situation leads to low productivity on family farms resulting in low family income and an inability to invest in agricultural inputs-including appropriate mechanization inputs. Increased poverty is leading to family disintegration with young, fit males migrating to urban centres both nationally and internationally; leaving women, the elderly and children to take on the burden of food production on the family farm.

Sustainable agricultural mechanization (SAM) can be described as mechanization that is economically feasible, environmentally sensitive and socially acceptable [17]. The United Nations' (UN) Food and Agriculture Organization (FAO) SAM website [18] elaborates on this basic concept as follows:

"Mechanization covers all levels of farming and processing technologies, from simple and basic hand tools to more sophisticated and motorized equipment. It eases and reduces hard labour, relieves labour shortages, improves productivity and timeliness of agricultural operations, improves the efficient use of resources, enhances market access and contributes to mitigating climate related hazards. Sustainable mechanization considers technological, economic, social, environmental and cultural aspects when contributing to the sustainable development of the food and agricultural sector."

The goal of this paper is to analyze the smallholder farm situation, to identify the key elements needed to include the concept of sustainability in future mechanization developments, and to suggest appropriate vehicles for delivering SAM technologies to farm families. The following sections examine more closely the various aspects and implications of SAM, the focus is on mechanization issues, other aspects, such as soil science, are dealt with briefly in order to put mechanization in context. In the next section we reprise the basic pillars of conservation agriculture which underpins the concept of SAM. Then the need to consider mechanization holistically along the agricultural product value chain is debated. Having examined the basic ingredients of SAM, we look at models for getting mechanization inputs delivered to the family farm better. The penultimate section considers the need for SAM development for specific situations (with particular reference to SSA), including R \& D and innovation platforms, before summing up with some concluding remarks. 


\section{The Need for Conservation Agriculture}

The use of soil cultivation implements, including mouldboard, disc and chisel ploughs, is one of the most energy hungry operations in agriculture; it is also the cause of soil structural damage and can create impermeable plough-pans at the depth of penetration. (Using hand-hoes for primary soil cultivation can have a similar effect with the creation of compacted hoe-pans in the soil profile-although it is a main driver of the agricultural mechanization discussion, especially in sub-Saharan Africa, that arduous hand-hoe work should be replaced with mechanization-hence hoe-pans should be a symptom of the past if SAM happens as envisaged. This desire is behind various mechanization initiatives in Africa and one of the aims of this paper is to ensure the application of SAM, and not merely the supply of mechanization inputs with no sustainability strategy in place.)

Tractor-powered ploughing uses vast amounts of energy to invert the top soil, this requires the use of high-powered tractors and can consume many litres of diesel fuel per hectare. In one study, in Nigeria [19] disc ploughing with a 3-disc plough at $30 \mathrm{~cm}$ depth consumed around $25 \mathrm{~L} / \mathrm{ha}$ with a $100 \mathrm{hp}$ tractor. This represents a major production cost and is one of the principal reasons given by farmers for reducing tillage operations. One farmer in Lincolnshire, UK estimates that by switching from mouldboard ploughing to direct seeding his total annual farm fuel consumption has fallen from 92 to $42 \mathrm{~L} /$ ha [20].

The physical damage caused by these traditional tillage practices includes the destruction of the natural channel systems in the soil profile created by roots and meso-fauna such as earthworms and termites. These are the channels which allow water to infiltrate and be stored in the profile pores, they also allow gaseous exchange with the atmosphere. Destroying the natural channel system with tillage implements greatly reduces the soil's capacity to absorb rainfall and irrigation water and increases the risk of run-off and soil erosion. If a plough-pan is also created, then the situation is made much worse as the now de-structured "arable layer" is perched on an impermeable layer which impedes the infiltration of water to deeper soil horizons. Soils in this condition suffer from a lack of available water and crops grown in them are increasingly prone to drought.

Tillage not only results in physical soil damage, but has a deleterious impact on soil organic matter and soil life. Soil organic matter (SOM) is the lifeblood of a soil. Formed through the actions of soil fauna and fungi on plant material (crop residues or applied mulch), SOM is the source of natural soil fertility and the principal agent in the formation of soil structure. SOM is oxidized when exposed to the atmosphere and solar radiation, and levels decline in tilled soils. Conversely they increase under no-till, conservation agriculture regimes.

Soil fauna, flora and fungi give a healthy soil its life and constitute the engine driving the production of soil fertility and maintaining a soil structure conducive to healthy crop growth and development. Disturbing the delicate balance and maintaining soil fertility through the application of inorganic fertilizers is not sustainable in the long term, and of course adds to production costs through the enforced use of expensive inputs.

\subsection{Climate-Smart Agriculture}

Farmers, especially smallholder farmers, have always been dependent on clement weather to raise crops and livestock and be food-secure. Today, with violent and erratic weather events becoming more widespread as the effects of climate change manifest themselves with increasing frequency, smallholder production systems are in danger of becoming ever more precarious. The global rise of interest in climate-smart agriculture (CSA) is a direct consequence of this situation, as is the need to reduce GHG emissions for the AFOLU sector as discussed previously in the light of IPCC analyses and predictions. CSA focuses on three pillars [21]: productivity to provide food security; adaptation both for extreme events and slower, long-term, climate change manifestations affecting both agriculture and the consequent food security implications, and; mitigating the effects of climate change through reduced GHG emissions (especially through carbon sequestration and reduced fuel consumption). 
FAO's concept of sustainable crop production intensification (SCPI) [22] recognizes the urgent requirement for increased agricultural productivity to feed a growing world population and the concurrent need to restore and nurture the planet's natural resource base. The essence of SCPI is encapsulated in the "Save and Grow" paradigm which uses an ecosystems approach to raise productivity in an environmentally friendly way. This includes enhancing SOM through the use of organic manures, mulches, cover crops and leguminous crops and trees while minimizing mechanical soil cultivation. Apart from improving soil health, other major aspects of achieving CSA are water management, including precision irrigation and the use of drought-resistant crop varieties; plant protection measures include the employment of crop rotations and effective (especially) biological weed control.

However, care must be taken to select appropriate CSA practices as an analysis of the global situation vis-à-vis CSA [23] indicates that there is a risk, because of the misallocation of financial and human resources, of promulgating agricultural systems that do not result in improved food security and increase the risk of accelerated climate change. Many CSA measures, designed to add resilience to agricultural systems to combat the impacts of climate change, are included in the practice of conservation agriculture which is the subject of the following section.

\subsection{Conservation Agriculture}

Interest in conservation agriculture (CA) has been growing over the last two decades (the seventh world CA congress is taking place in Argentina in 2017). The practice is spreading by an estimated 10 million hectares a year [24] and now covers approximately 11 percent of global arable cropland. CA is far from being a single practice employed over this vast area, instead it is a complementary set of three general principles which are adapted locally to become compatible with the location specific environment. Paraguayan smallholder CA practitioners would have a very different complex of technologies and practices compared to their counterparts in the highlands of East Africa, for example. However the general principles will still apply and will be common to the local adaptations in both regions. These general principles are as follows (see, for example, [24]):

- Minimal soil disturbance. The damaging impact of soil tillage has been discussed in the previous section, in CA seed, fertilizer and transplants are placed in the desired position in the soil profile with the least amount possible of disturbance to the soil. Direct seeding and planting is the goal and the mouldboard or disc plough plays no role, although it may be necessary to repair damaged soils prior to embarking on a CA regime. This may entail breaking a plough-pan with a subsoiler or chisel plough, or removing ridges and furrows with one last pass of the mouldboard plough, but these operations will not be necessary once CA has been introduced.

- Maintaining a permanent organic soil cover. Keeping the soil surface under organic cover is a very important means of conserving soil moisture, improving soil structure and water infiltration and providing a substrate for conversion into SOM and soil fertility. Soil organic matter cover can also play an important role in weed suppression. Cover will comprise the residues of the previous crop, but this can be augmented by the use of crop associations, rotations and cover crops (especially leguminous cover crops). The maintenance of soil cover can be difficult, especially in semi-arid regions with low dry season precipitation, and where livestock have access to crop residues [25]. In these situations CA farmers may need to provide additional biomass for livestock feed including fodder banks of perennial grass species and trees for dry season browsing [26].

- Maintaining biodiversity in crop production. The value of crop rotations to maintain soil fertility, and reduce pest and disease incidence, has long been understood. CA strives to go further than this and encourages the use of crop associations, relay cropping, cover crops and agroforestry. The use of legumes in association with cereal crops like maize is especially useful (Figure 1). 


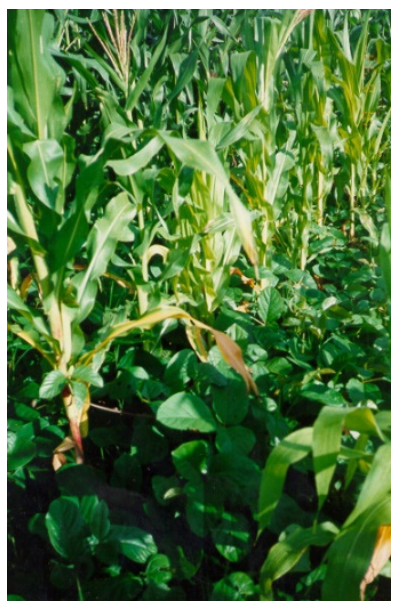

Figure 1. Maize intercropped with Canavalia ensiformis. The leguminous Canavalia fixes nitrogen which can be used by the cereal crop.

\subsection{Mechanization of $C A$}

\subsubsection{Seeders and Planters}

Implementing CA requires some specialist equipment [27], especially for sowing seeds through the soil surface mulch of crop residues or cover crops. The process starts with crop residue treatment-residues should be spread evenly across the soil surface behind the combine harvester and this may require a spreader to be fitted at the rear. The seeder (delivering a continuous flow of small seeds) or planter (delivering large seeds at discretely spaced intervals) has two main ways of introducing seed and fertilizer through the surface vegetation. In conditions of light coverage, narrow chisel tined openers can be used (Figure 2). The tine opens a slot behind which seed and fertilizer can be delivered to the required depth.

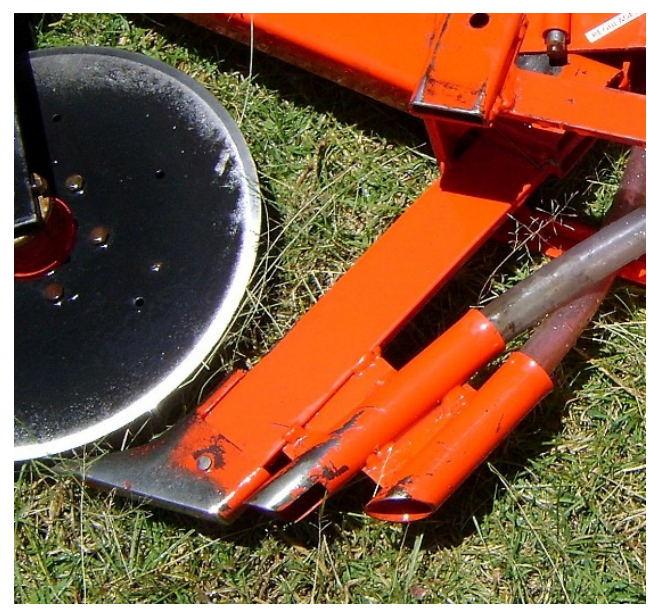

Figure 2. Narrow chisel-tined slot openers for seed and fertilizer placement are suitable for low surface residue situations. A vertical disc preceding the opener will ease residue flow.

Single discs, inclined to the direction of travel can open a slot in the soil so that seed and fertilizer can be delivered behind the disc in a way similar to a chisel-tined opener (Figure 3). In heavy surface residue conditions, the best approach is the use of double disc openers. These are discs of different diameters, offset to the direction of travel, which can cut through residue, open a ' $V$ '-shaped slot and deliver seed and fertilizer between the discs (Figure 4). In all cases where it is necessary to cut through 
surface vegetation, a vertical disc preceding the slot opener will usually facilitate smooth residue flow. Keeping soil disturbance to a minimum should always be the aim and the cross-slot opener achieves this by cutting through residue with a vertical disc and delivering seed on one side and fertilizer to the other in horizontal slots produced by inclined lateral wings [28].

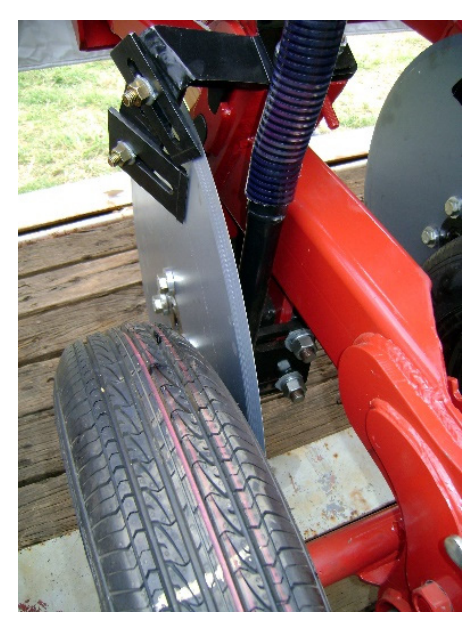

Figure 3. Single inclined disc opener. Seed and fertilizer are delivered behind the disc.

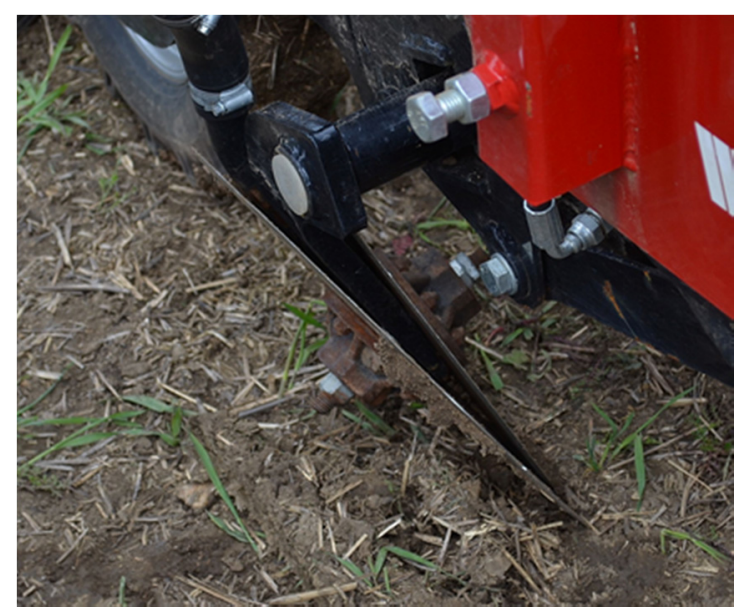

Figure 4. Double-disc opener, in this case not only inclined to the direction of travel, but vertically as well. This provides better seed coverage and less surface soil disturbance.

Rice residue is notoriously difficult to cut with vertical discs and one method to deal with heavy residue situations is by lifting the residue with rotating flail-blades before sowing into the cleared surface and depositing the mulch back on top of the seeded soil. This concept, incorporated in the "Happy Seeder" [29] has subsequently been modified to cut and lift the residues with rotating flails either side of the chisel-tined slot opener and seed and fertilizer delivery tubes (Figure 5). 


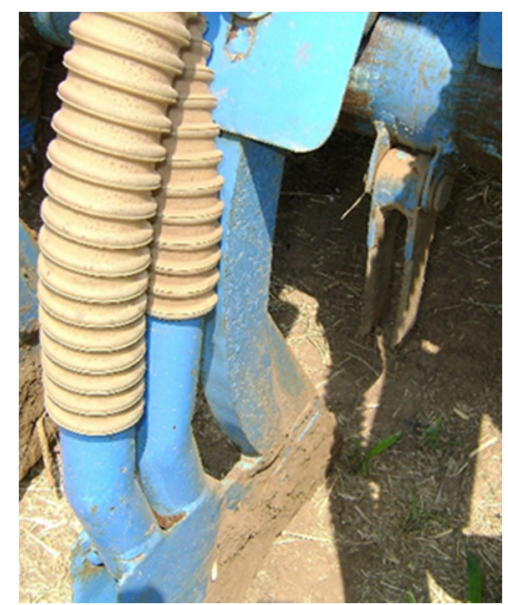

Figure 5. The Turbo Happy Seeder manages rice residue by flailing and lifting it on either side of the chisel-tined no-till slot opener.

Planters for manual use can be as simple as a pointed stick with a small container tied to the farmer's waist for seed and/or fertilizer. An improvement on this basic idea is the hand-operated jab planter which can deliver seed and fertilizer through separate sharp beaks which are closed on entering the soil and opened at planting depth (Figure 6).

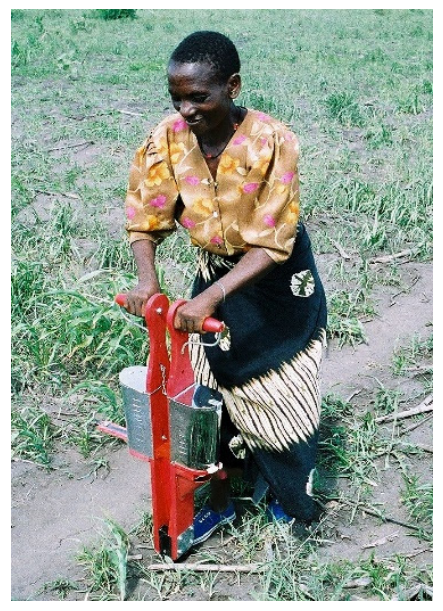

Figure 6. A manually operated jab-planter with hoppers for seed and fertilizer.

Reduced tillage, cultivating a strip of soil for crop establishment is an increasingly popular option. Tractor, or draught animal, powered rippers (narrow chisel tines) are used to cultivate a strip of soil into which the crop is planted manually (perhaps with a jab-planter) (Figure 7). Power tillers can be modified by adjusting the lateral placement of blades so that strips are cultivated in the soil. A seed hopper and metering mechanism can be mounted over the rotary cultivator to achieve strip tillage and seed placement in one pass [30]. 


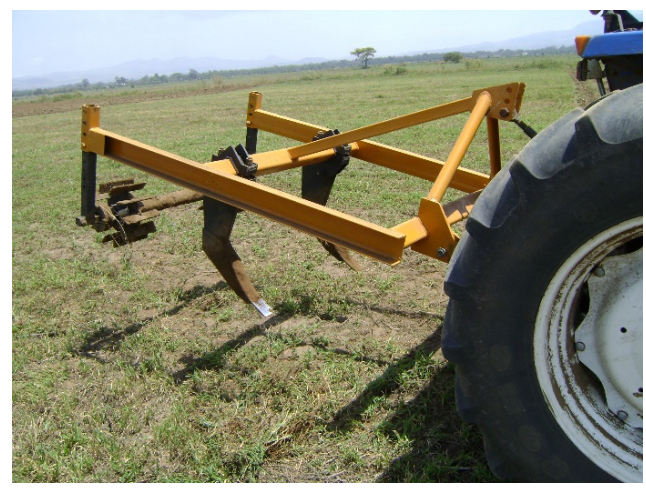

Figure 7. A tractor-mounted chisel-tined ripper which can be used to create narrow tilled strips for crop establishment.

\subsubsection{Power Sources}

The power sources used for CA mechanization include tractors (both four-wheel-4 WT, and two-wheel-2 WT); draught animals and humans; the wide range of possible power sources can be seen on the FAO CA website [31]. Generally speaking, and as we have seen above, the power requirement for $\mathrm{CA}$ is considerably less than that for tillage-based agriculture-approximately half the energy is expended with no-till CA and so the power of motorized units (4 WTs and 2 WTs) can be halved and this is one of the main attractions of CA for farmers.

\subsubsection{Weed Control and Cover Crop Management}

Weeds and cover crops can conveniently be managed with the use of herbicides, but this is becoming somewhat controversial as public and environmentalist preferences turn towards a reduction in the use of agro-chemicals. Other options are available and should be employed whenever possible. Cover crops, residues and weeds can be conveniently managed with knife rollers prior to direct drilling-knife rollers are cylinders with blades which crimp the vegetation without chopping it and in many cases this is sufficient to kill the plants (Figure 8).

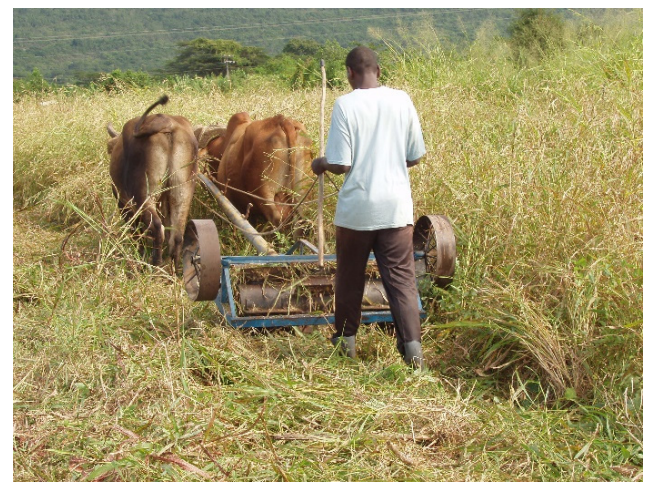

Figure 8. An animal-drawn knife roller managing weed growth prior to direct seeding.

Weeds can be managed manually by rogueing, mechanically by surface scraping or by removing flower heads above the crop with machines such as a "Weed Surfer" which has a series of rotating blades to decapitate the flowering weeds [32]. The best way to manage weeds is through competition with main crops, associated crops and cover crops; keeping the soil covered with vegetation will suppress weeds and cover crops that include a wide mixture of species are probably the best option. Soil cultivation for weed control is not an option in CA. 
If herbicides are to be used, then the conventional range of sprayers can be employed. These range from the ubiquitous back-pack (or knapsack) lever-operated sprayer to animal-drawn and tractor-mounted boom sprayers. One particularly useful innovation for smallholder farmers is the idea of mounting a back-pack sprayer on a small, wheeled, chassis; the pump lever is operated by an eccentric off a drive wheel. The rig, with a 4-nozzle, 2-metre boom is pulled behind the operator ensuring that he is kept well away from possible spray contamination (Figure 9).

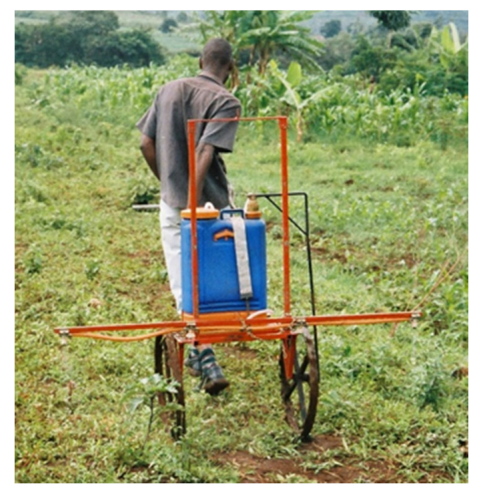

Figure 9. A back-pack sprayer mounted on a wheeled chassis. The sprayer pump is actuated by an eccentric from one of the wheels, the 2-m boom has four nozzles. A manually operated return valve is required to control pressure and prevent wheel skid.

\section{Mechanization along the Value Chain}

Increased economic growth in the rural sector with its concomitant improvement in employment possibilities is a key to poverty reduction and so helps with the achievement of the UN's Sustainable Development Goal 1 (An end to poverty). Mechanization in its broadest sense has great potential to increase productivity and improve livelihoods, not only in primary agricultural production (both crop and livestock) but also along the value chain of that production. This will include post-harvest operations such as storage and processing (shelling, milling and husking). It can also include food processing from (fairly) simple packing of fresh produce for supermarket chains (Figure 10) to more industrial type processing, for example of dairy products like yoghurt and ice-cream or juice extraction from aloe (Aloe vera) [33].

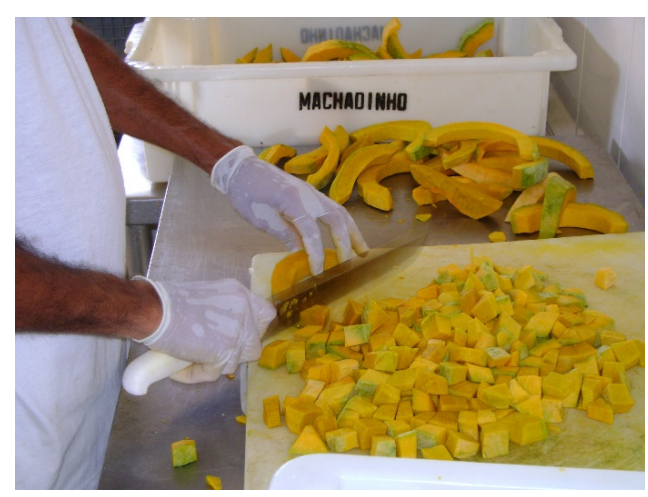

Figure 10. Small-scale processing and packaging of vegetables for local supermarkets.

Whereas such business ventures, requiring as they do a sound business plan and financial backing, are well within the grasp of larger producers, for smallholders some form of collaborative action will usually be required. Farmer cooperatives can be the solution and there are many examples of farmer cooperatives organized to provide services as varied as crop cleaning, drying and storage, 
to food processing and manufacturing [34]. The opportunities that arise will be specific to particular locations or regions and their identification can be a useful contribution from NGOs working with rural communities. Cooperatives are also particularly useful for the supply of production inputs (i.e., improving input supply chains) including farm machinery, as they, as bulk buyers, can demand preferential prices from suppliers, something that would not be possible for individual farmers.

The value chain does not end with processing and packaging. There is still a requirement for marketing and transport and it is in this latter category that mechanization input suppliers may find a useful clientele that will allow them to expand their businesses throughout the year. A well-functioning or developing value chain is one key to increasing prosperity and reducing poverty as well as the creation of alternative (and often better paid) jobs compared with subsistence, hand-hoe-powered, agricultural production. Mechanization inputs are the drivers of this transformation process and public-private partnerships are probably the best-bet option for making value chains work in all stakeholders' interests.

A world congress of the International Commission for Agricultural Engineering (CIGR) included a workshop (organized by FAO) which focused on "creating sustainable and viable machinery supply chains for enhancing mechanization, and of using technology to add value to, and increase the quality of, agricultural products" [35]. This neatly encapsulates our point on ensuring a well-functioning mechanization input supply chain and output value chain and some examples of success stories (with an SSA focus) discussed in the workshop can be summarized as follows:

\section{Challenges for agricultural mechanization}

Access to mechanization by smallholder farmers is a pressing necessity to enable increases in their labour and land productivity. This will require clear guidance from a transparent public sector, free from corruption, to provide an environment conducive to enthusiastic and profitable private sector participation. Local manufacture of locally adapted mechanization inputs should be encouraged and facilitated and demand for mechanization services should be increased through the creation and nurturing of common interest farmer groups (such as CA clubs) and the provision of credit and financial incentives. Mechanization technology transfer is beneficial, especially through south-south collaboration where there is a better understanding of conditions and constraints. At the same time, it is important not to lose sight of the value of participatory adaptation of equipment for local conditions. The conservation of natural capital (especially soil, water and forests) requires a renewed focus on sustainable land management. Supply chains for sustainable mechanization options need to be strengthened to encourage increased demand. Because of rural-urban migration and the impact of pandemic diseases, female-headed farm families are becoming more prevalent, especially in SSA. Improving women's access to farm power through the provision of suitably designed equipment needs to be addressed by the actors in the farm power provision supply chains.

\section{Using technology to add value and quality}

The public sector can play a major role in supporting private sector initiatives in the SAM area. Examples of support include funding for market studies, public-private cooperation to innovate in the value chain, and programmes to better link research institutions to the private sector. Consideration of the entire value chain can help to avoid the build-up of constraints (bottlenecks) in the value addition process. That is to say avoiding the situation where the resolution of one problem may give rise to additional problems down the line. Participatory technology development should involve partnerships between manufacturers, researchers and user groups, this will build local capacity for the development of food production and processing technology, rather than dependence on importation. Again, environmental protection is of fundamental importance. Food processing has the potential to be a major polluter-but thinking holistically and considering food processing industry "waste"; products as valuable nutrient inputs for food production is the sustainable solution. 


\section{Making Mechanization Available}

Smallholder farmers, acting on their own, usually find that investment in mechanization technology is too expensive a proposition for them. As we have discussed above, the application of sustainable agricultural practices requires specific equipment, especially for seeding through vegetative soil cover. Both the availability and affordability of CA-specific equipment are of great importance to scale out CA, but individual smallholders would struggle to acquire the necessary tools. In this case, the possibility of specialist CA service provision should be considered [36]. For this to become reality, appropriate entrepreneurs-willing to provide such services-will need to have access to the correct equipment and this may involve facilitating their access to financial credit. Public sector planners will see that the mechanization "business" can play an influential part in private sector development and so is deserving of some public sector support. This support can take the form of planned strategies to rationalize and promote mechanization [37] which will include partnerships (public-private partnerships or PPPs) to facilitate equipment supply chains (especially through support of local manufacture), supply credit to the rural sector and share financing risks, create improved extension services, demonstrations and farmer-oriented messages with a focus on sustainable agricultural mechanization. Such training would focus specifically on business skills and sustainable agriculture technology practical skills [38]. One example of public sector support for financing is that of the Brazilian government through its More Food (Mais Alimentos) programme where concessional loans are offered for the purchase of agricultural machinery. The programme has been extended from Brazil to Mozambique, Ghana, Zimbabwe and Kenya to promote family farming [39]. The idea of making finance available to farmers to encourage vertical integration between input suppliers, farm producers and food processors is not always met with unanimous approval. Brazilian and Japanese investment in the ProSAVANA programme in Mozambique is a case in point [39] where loans are provided to integrate smallholder farmers into agribusiness value chains. ProSAVANA has, however, ignited controversy with civil society organizations arguing that local farmers will be disenfranchised and the beneficiaries will be Brazilian and Japanese multinationals along with the local Mozambican elite. The remainder if this section examines models that are being used to deliver mechanization services to smallholder farmers. Many of them are models discussed during a December, 2016 meeting in Nairobi, Kenya on models for sustainable agricultural mechanization in SSA [40], although not all have an exclusively African focus.

\subsection{Machinery Rings in Germany}

Machinery rings in Germany are a response to a reduced labour force and inefficient machine use on individual small farms [41], currently there are approximately 230 local machinery rings (MRs) with 192,000 members. MRs are organized by the farmers themselves and constitute a modern centre of a range of services and good technical knowledge. Investments can be made in common or, more usually, by individuals and there is a value chain approach (e.g., planting, weeding, harvesting, loading, cleaning, transport of sugar beet). Machines are hired by farmer ring members and come with a qualified operator.

The experience is that MRs are very successful as the rules are clear and transparent and prices are reasonable. Farmers declare themselves to be in favour of this means of working together to get modern mechanization at an affordable price.

There would appear to be good potential to expand this model to developing country situations and there is good scope for PPPs (e.g., in the design of policy frameworks for facilitating the finance of machinery acquisition) which should be explored further.

\subsection{Cooperatives for Promoting Mechanization}

Farm machinery cooperatives (Coopératives d'Utilisation de Matériel Agricole-CUMAs) are highly participatory (rather than passive) collective investments, managed by farmers in independent groups 
in the same territory. An illuminating paper [42] gives details of how the CUMA movement in France has contributed to the removal of the major barriers to the economic and social development of family farmers. The history of the CUMA movement shows how social capital is a critical resource in overcoming some incentive problems; the CUMAs have succeeded in creating effective cooperatives through the development of a dense fabric of relationships. The idea of CUMAs has now been established in Benin [43] with three principal aims: to facilitate access to mechanization; to overcome financing difficulties and to increase the profitability of the investment in farm machinery. The result has been an increase in the cultivated area (by 350 percent) and better cultivation to produce increased incomes, enhanced standards of living, and social transformation with the increase in entrepreneurship and involvement of youth. CUMAs promote strong relationships within themselves and they react positively with other unions and cooperatives in the national and international institutional environment.

\subsection{International Research Centres}

International research centres (especially those of the CGIAR-Consultative Group on International Agricultural Research) are taking an increasing interest in developing technology for sustainable mechanization. These are PPPs as the private sector (farmers and manufacturers) are intimately involved, as is the public sector through the technology development and financing alternatives. One example is AfricaRice, a member of the CGIAR consortium whose membership comprises 26 countries in West, Central, East and North Africa [44]. Mechanization is a priority area in their strategic plan and there is an Africa-wide mechanization task force to get appropriate technology into the hands of producers and processors; the main activities are: research, fabrication, out-scaling and training. AfricaRice collaborates with public-private partnerships to promote SAM with many technologies along the value chain from transplanters to weeders to threshers to parboilers. The 'ASI' light thresher is particularly suitable for operation by women who are offered agribusiness skills development advice through innovation platforms.

After a lapse in interest, other international research organizations, notably the International Rice Research Institute (IRRI) and the Maize and Wheat Improvement Centre (CIMMYT) are again engaging with the importance of mechanization as a fundamentally necessary agricultural input.

\subsection{International Development Organizations}

Another example of PPPs is the collaboration between the UN Industrial Development Organization (UNIDO) and private sector heavy equipment manufacturers to establish operator training centres in various African countries. Examples of human capacity development include [45]: the Japan heavy equipment operator school (JHEOS)—Liberia (Komatsu); the Zambia industrial training academy (ZAMITA)-Zambia; the Heavy duty equipment and commercial vehicles academy (HDECoVA)—Ethiopia and; the Académie engins lourds et véhicules commerciaux (AGEVEC)-Morocco.

Public-private development partnerships (PPDPs) combine the expertise and resources of the private sector (e.g., Volvo, Festo, Scania) with the public sector and development sector (e.g., UNIDO, SIDA (Swedish International Development Cooperation Agency), USAID (United States Agency for International Development), etc.) to provide a public service by creating a skilled work force.

\subsection{CASU Project, Zambia}

Creating a sustainable demand for mechanization services is a critical element in out-scaling SAM and the FAO-implemented Conservation Agriculture Scaling-up Project (CASU) in Zambia focuses on raising demand for this input [46]. Challenges with smallholder mechanization, which need to be overcome, include technical problems, from land preparation to planting, weeding and harvest; and postharvest handling. There are also limited financing opportunities due to: the low value of 
draught animal power (DAP) equipment which is not "economic" for financing institutions; the limited collateral available to smallholder farmers and; the high interest rates required.

The CASU project promotes CA mechanization in a variety of ways including harnessing the potential of existing service providers to focus on CA; linking CA mechanization to on-going social protection programmes (e.g., by using e-vouchers to stimulate demand); the creation of collaborative PPPs for financing and service provision and; the bundling of services (e.g., by offering planting + weeding + harvesting + processing + transport).

\subsection{Private Sector Driven Agricultural Mechanization Programme (PSDAMP) in Nigeria}

In Nigeria the PSDAMP is a PPP involving the Ministry of Agriculture, financial institutions, agro-machinery manufacturers and service providers [47]. This PPP, initiated in 2012, sets up agricultural equipment hiring enterprises (AEHEs) where there is demand from farmers to hire or lease mechanized equipment for a variety of value chains. AEHEs are needed for a range of reasons including: small and fragmented land holding sizes and poor resource base of smallholder farmers; inadequate skills for operating and maintaining complex equipment; endemic corruption, and; a lack of after sales technical support.

AEHEs are created as safe housing and workshop centres to service a minimum of 1500 ha. A typical list of equipment (costing USD 60,000-123,000) for an AEHE is:

- 3-5 units of tractors + basic implements.

- 5 power tillers.

- 2 mini-harvesters.

- 3 threshers.

- 1 boom sprayer.

Only equipment with a certificate from the National Centre for Agricultural Mechanization (NCAM) is eligible and all foreign equipment must have local technical back-up support. Funding for an AEHE is divided between the public and private sectors and is for four years at an interest rate of 7 percent. The AEHE is owned by service providers and can comprise cooperatives or other farmer groups, individual farmers or private investors. They are run by a 5-person team (leasing manager, accountant, field supervisor, mechanic and security guard); capacity building is built in for technical and managerial staff. The investment is secured against risk by a variety of insurance schemes and machinery tracking. Service back-up is assured and periodic technical training programmes are given in collaboration with manufacturers.

A total of 250 AEHEs is envisaged and to date there are 140 AEHEs with 590 tractors and ancillary equipment.

\subsection{Other Examples of Successful Ppps for Mechanization Service Provision}

The German Development Institute (Deutsches Institut für Entwicklungspolitik-DIE) offers descriptions of a range of PPP models for mechanization service provision [48]. Among the most impressive are the following examples:

MyAgro

MyAgro is a not-for-profit organization active in Mali and Senegal. It is a layaway savings scheme whereby local vendors sell scratch cards for farmers who text the code to deposit their savings in a myAgro account; MyAgro can then deliver high quality seeds, fertilizer and tools. The result is a secure savings scheme and guaranteed, timely input supply. MyAgro provides training and support services on climate-smart and input-saving practices (such as CA). Timely delivery of quality-guaranteed inputs is assured (an especially important aspect for farmers in remote locations). MyAgro also adapts tools to local needs, especially the needs of women.

The myAgro programme provides a confidential savings method, avoiding the social problems sometimes associated with traditional savings group models. The system is also helpful in ensuring 
that savings are used for their dedicated purpose (rather than run the risk of being diverted to cover unforeseen emergencies that may crop up) and has resulted in improved access to mechanization inputs.

\section{Hello Tractor}

Hello tractor is a social enterprise in Nigeria which provides a machinery hire service. Tractor services are requested by text message and prepayment is made by mobile phone. After satisfactory completion of the task, payment is released to the "smart" tractor owner. Anonymity means that women are more able to supply services.

NWK

NWK in Zambia is a commercial cotton producer and acts as an intermediary between farmers (out-growers) and the bank. Farmers pay according to their cash flow (usually at harvest) and NWK pays for services to be provided when needed. The result is high quality mechanization services provided on time to otherwise vulnerable farmers.

\section{AGCO Future Farm, Zambia}

AGCO's Future Farm concept aims to develop a sustainable food production system able to increase farm output through more efficient resource utilization [49]. One ongoing effort is to develop an agricultural machinery hire services model [50] which will indicate the level of income a local agro-dealer and service provider needs to achieve to be viable. This will come from products and services that can be provided to local emerging and small scale farmers, namely contracting services, sales of seed, fertilizer, agro-chemicals and other inputs.

The aim of the model is to provide a tool that enables someone to sit down with an entrepreneur and have an open discussion about what is actually viable from a business perspective. The idea is to figure out what could be possible and start to develop a business case that makes stakeholders comfortable with the proposal.

Several general conclusions can be drawn from the examples outlined above. Firstly only demand-driven and profitable mechanization is viable, service providers and all the other actors in the supply chain need to make a viable living out of the process. Mechanization technology needs to be adapted to farm size and endowment context, low intensity technologies (e.g., 2 WTs and DAP) are feasible at farm level, but higher intensities require shared ownership. The finance provision of all actors needs to be considered in the mechanization supply chain [51].

\section{The Need for the Development and Screening of SAM Technologies and Local Manufacture}

As we have seen, mechanization for smallholder farmers has been somewhat neglected for the past few decades. Efforts to mechanize via public sector service providers in many countries generally failed due principally to unresponsive management structures, soaring costs and subsidized prices. They were generally poorly run and financial losses (Figure 11).

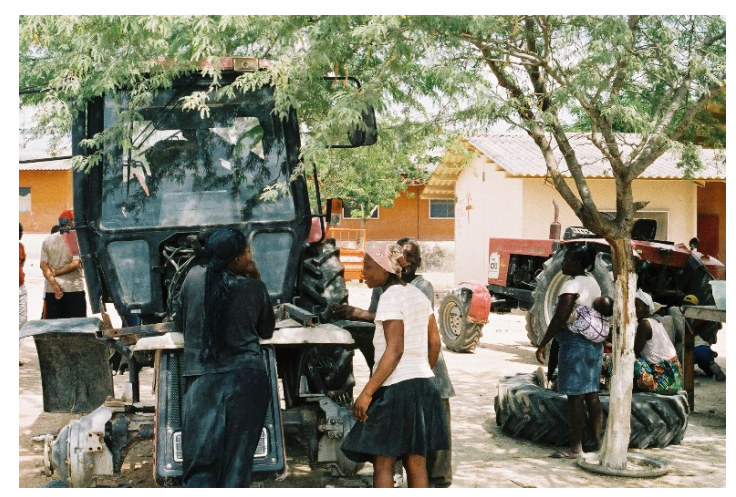

Figure 11. Public sector farm machinery services targeting smallholder farmers have usually been financial failures. 
Research and development efforts aimed at mechanization options for smallholder farmers have not always been effectively directed with a focus on identifying needs with the key stakeholders of users and manufacturers; rather inappropriate "solutions" have often been developed in isolation and have subsequently withered on the vine after the fanfare of initial promotion [52] (Figure 12).

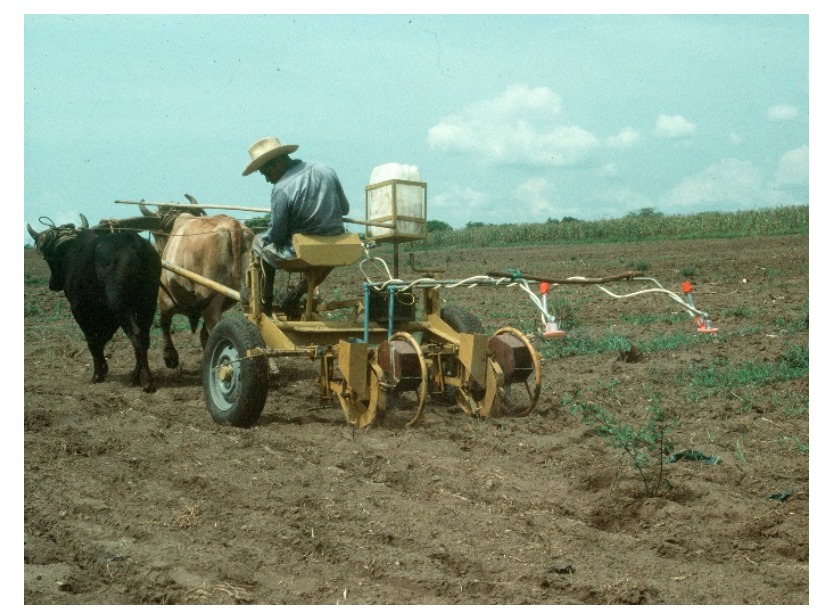

Figure 12. The development of animal-drawn wheeled toolcarriers attracted considerable development effort in the 1980s; however farmer adoption was minimal.

During the previously mentioned consultative meeting on mechanization strategies for SAM, held in Nairobi, Kenya in December 2016 [53] two urgent needs were discussed which will put efforts to provide smallholder farmers with appropriate mechanization options, firmly at the forefront of rural development planning. These were support for the establishment of multi-stakeholder innovation platforms, and the creation of a network of centres of excellence for the development and promotion of SAM options for smallholder farmers. An innovation platform is an on-line forum for the dissemination of SAM technology and knowledge; a SAM centre of excellence is a hub for the development of relevant information, training, development and testing. These two proposals will now be discussed.

\subsection{Sustainable Mechanization Knowledge Exchange Platform}

There is a need for a platform to share knowledge and experience and give visibility to SAM equipment and its application. The platform would bridge the gap and forge a link between machinery users and manufacturers and its outcome would be to demonstrate how to adapt and/or develop technologies for SAM from the knowledge exchange.

The platform would distinguish between short-term and long-term development. Product information would be presented from the users' (usually farmers but also support players such as extension officers) perspective. Participation would be encouraged and opinions on equipment shown. Surveys, statistics and reports would also be included.

An important issue would be technology transfer-matching farmers' needs to manufacturers' offers. There would also be a strong content on capacity building and market information. Longer-term issues to be included would be newly developed equipment, and finance options and models. A country focus would be appropriate for many themes.

The organization could be a collaboration between manufacturers' associations and an agricultural development organization. The platform would need a kick-start from donors and thereafter should be self-sustaining with revenue from advertising and fees from machinery manufacturers wishing to place their products.

The platform should be global as there is a global need for comprehensive information on existing demand (especially for machinery suppliers). Current platforms do not have this information and with this new platform the target would be farmers and farmers' associations as a priority. The platform 
would offer technology as well as knowledge and include machinery that has the potential to be sustainable (i.e., it would not be a purely commercial website). It is to be hoped that the challenge to investigate further the concept of a SAM platform will soon be taken up and implemented.

\subsection{Regional Centres for SAM}

Asia is well served by the UN Centre for Sustainable Agricultural Mechanization-UN-CSAM, based in Beijing, China [54]. CSAM grew out of the success of the Regional Network for Agricultural Machinery RNAM and the UN Asian and Pacific Centre for Agricultural Engineering (UNAPCAEM). CSAM became operational in 2012.

A strong case can be made to establish a similar centre with an African focus and possibly also for Latin America which would build on the pioneering work already achieved in Brazil [55]. In the case of SSA, the concept could be a network of centres of excellence. The Network would comprise a central hub (with a secretariat) and regional centres covering West, Central, East and Southern Africa. It would also need to have strong links to North Africa and other networks globally.

- The principal objective of the Network would be to improve smallholder farmers' access to appropriate SAM technologies to help them to improve their livelihoods. It would achieve this through a variety of methods including: collecting and sharing information and knowledge; training and capacity building; testing and evaluation of technologies (although all technologies would be allowed to flourish or fail, there would be no imposition) and; the preparation of catalogues of successful stories (but not prototype development). In addition the Network should be active in the provision of standards, using Organization for Economic Co-operation and Development (OECD), International Organization for Standardization (ISO) and Asian and Pacific Network for Testing of Agricultural Machinery (ANTAM) codes where applicable.

Complementary centres in SSA and globally. In West Africa there are already nine value chain centres of excellence and a tenth is being added (with World Bank funding) on agricultural mechanization. This has the potential to be a West African regional centre of the Network. There is also positive experience with the UN Centre for Sustainable Agricultural Mechanization (UN-CSAM).

In SSA the regional centres can specialize on specific roles, such as testing or capacity building. The Network itself will identify the best choices for regional centres of excellence and this should be undertaken in close collaboration with: the: Governments of the countries involved; the private sector, especially manufacturers of agricultural machinery; farmers' associations seeking to improve access to SAM technology; SAM service provider associations and; National and international institutions research centres, universities, UN organizations (such as FAO and UNIDO).

Funding is likely to emanate from a variety of sources. The private sector is only likely to be interested in joining after initial funding and institutional set-up, once this has happened, they can be invited to become corporate members. Funding for the establishment of the Network could include: the World Bank and UN agencies; foundations (e.g., the Bill and Melinda Gates Foundation); National development agencies; Intergovernmental organizations and; the Private sector.

\section{Conclusions}

Sustainable agricultural mechanization involves the application of different forms of power sources in conjunction with appropriate equipment able to do useful work in agricultural production and along the agri-food value chain. Thus, mechanization must meet farmers' needs efficiently and effectively and result in improved farm productivity and reduced drudgery, as well as contributing to the development and competitiveness of the food supply chain. To be sustainable, mechanization must take economic, social, environmental, cultural, and institutional issues into account [56].

As we have seen, SAM holds great potential for improving incomes, livelihoods and employment opportunities for some of the often overlooked segments of rural society: women, children, the elderly and youth. SAM strives to offer life-changing mechanization inputs in a culturally sympathetic way and 
so these groups can be helped to advance while not upsetting cultural norms, or by forging acceptable new ones. However, it is acknowledged that mechanization is part of a process of transformation from subsistence-oriented farming to market-oriented production. Yet, without having a positive effect on natural capital, mechanization cannot be sustainable and this, perhaps, is the key final message. Sustainable mechanization does not destroy biodiversity nor does it mine natural resources-if mechanization does not result in these impacts then it cannot be called sustainable-despite any process of transformation that it entails.

The focus for SAM should be on smallholder farmers, half a billion of whom account for 80 percent of food production in the developing countries of Asia, Latin America and Africa. Because this group is relatively poor in resources, the best way to give them access to SAM is via professional (trained) private sector SAM service provision. SAM technology is, however, available for and applicable to all farm types and sizes and all power sources (from manual to DAP to engine). The world's farming is turning to climate-smart conservation agriculture at the rate of over 10 million hectares annually. SAM can be provided to the smallholder sector in a number of diverse ways; however, although services should always be provided by the private sector (given the almost universal failure of public sector mechanization provision) the public sector still has an important role to play. This can be through nurturing an attractive environment in which the private sector can do business and includes providing infrastructure, finance and appropriate 360 degree training, entailing all aspects of SAM, in one of the many types of PPP that have been successfully implemented in many countries. Potential trainees should be pre-selected through a rigid process-it should be made clear that they are not just undergoing training but would later on be required to make a business decision to become a SAM service provider with all the entrepreneurial risks implied. Consequently the training will have to cover all aspects from mechanization business type selection to knowledge of environmental sustainability to climate smart, energy efficient ways of machinery application.

To promote the development and scaling out of SAM, two proposals are offered and described. The first is the establishment of a global knowledge exchange platform which would disseminate proven information on SAM technologies, practice and experience in a format readily understandable to, and accessible by, the smallholder farm family community. The second is the establishment of Centres of Excellence for the development and testing of SAM technologies. Based on the positive contribution being made by CSAM in Asia, other regional centres would definitely be recommended for Africa (especially SSA) and, possibly, for Latin America.

Author Contributions: Brian Sims developed the contents and structure of the paper and prepared the first draft. Josef Kienzle enriched the original draft with additional valuable information.

Conflicts of Interest: The authors declare no conflict of interest.

\section{References}

1. Wikipedia. World Population. Available online: https://en.wikipedia.org/wiki/World_population (accessed on 8 March 2017).

2. Buffet, H.G. Foreword. In Conservation Agriculture for Africa: Building Resilient Farming Systems in a Changing Climate; Kassam, A.H., Mkomwas, S., Friedrich, T., Eds.; CAB International: Wallingford, UK; Boston, MA, USA, 2017; pp. xi-xiii.

3. Asia Population. Available online: http://www.worldometers.info/world-population/asia-population/ (accessed on 9 March 2017).

4. Global Assessment of Human-Induced Soil Degradation (GLASOD). Available online: http:/ /www.isric. org/projects/global-assessment-human-induced-soil-degradation-glasod (accessed on 9 March 2017).

5. Jones, A.; Breuning-Madsen, H.; Brossard, M.; Dampha, A.; Deckers, J.; Dewitte, O.; Gallali, T.; Hallett, S.; Jones, R.; Kilasara, M.; et al. Soil Atlas of Africa; European Commission, Publications Office of the European Commission: Luxembourg, Luxembourg, 2013; p. 176.

6. Agriculture at a Crossroads, Findings and Recommendations for Future Farming: Water. Available online: http:/ / www.globalagriculture.org/report-topics/water.html (accessed on 10 March 2017). 
7. IPCC. Climate Change 2014: Synthesis Report. Contributions of Working Groups I, II and III to the Fifth Assessment Report of the Intergovernmental Panel on Climate Change; IPCC: Geneva, Switzerland, 2014; p. 151.

8. FAO. The Future of Food and Agriculture-Trends and Challenges; Food and Agriculture Organization of the United Nations: Rome, Italy, 2017; p. 163.

9. European Commission. Climate Action. Available online: https://ec.europa.eu/clima/policies/ international/negotiations/paris_en (accessed on 12 March 2017).

10. Parry, M.L.; Canziani, O.F.; Palutikof, J.P.; Van der Linden, P.J.; Hanson, C.E. Climate Change 2007: Impacts, Adaptation and Vulnerability. Contribution of Working Group II to the Fourth Assessment of the Intergovernmental Panel on Climate Change; Cambridge University Press: Cambridge, UK, 2007; p. 976.

11. FAO. The State of Food and Agriculture. Innovation in Family Farming; Food and Agriculture Organization of the United Nations: Rome, Italy, 2014; p. 139.

12. Singh, G.; Zhao, B. Agricultural mechanization situation in Asia and the Pacific region. Agric. Mech. Asia Afr. Lat. Am. 2016, 47, 15-25.

13. Singh, S. Agricultural machinery industry in India. Agric. Mech. Asia Afr. Lat. Am. 2016, 47, $26-35$.

14. Yuanen, G. The current situation and future of agricultural machinery industry in China. Agric. Mech. Asia Afr. Lat. Am. 2016, 47, 109-114.

15. FAO. Agricultural and Food Engineering Services Technical Report 3. In Farm Power and Mechanization for Small Farms in Sub-Saharan Africa; Food and Agriculture Organization of the United Nations: Rome, Italy, 2006; p. 65.

16. Mrema, G. The process of developing a draft framework for SAMS for the transformation of agriculture in Africa: Sending the hand-hoe to the museum. In Proceedings of the Consultative Meeting on Mechanization Strategy: New Models for Sustainable Agricultural Mechanization in Sub-Saharan Africa, Nairobi, Kenya, 1-3 December 2016.

17. Sims, B.; Kienzle, J. Making mechanization accessible to smallholder farmers in sub-Saharan Africa. Environments 2016, 3, 11. [CrossRef]

18. FAO. Sustainable Agricultural Mechanization. Available online: http://www.fao.org/sustainableagricultural-mechanization (accessed on 16 March 2016).

19. Adewoyin, A.O.; Ajav, E.A. Fuel consumption of some tractor models for ploughing operations in the sandy-loam of Nigeria at various speeds and ploughing depths. Agric. Eng. Int. CIGR J. 2013, 15, 67-74.

20. Sims, B. A Decade of Conservation Agriculture: Farm Walk at Thurlby Grange Farm, Bourne, Lincolnshire. 2014. Available online: http://www.taa.org.uk/assets/group-articles/Decade $\% 20$ of $\% 20$ CA $\% 20$ at $\%$ 20Reynolds.pdf (accessed on 8 June 2017).

21. Campbell, B.; Dinesh, D.; Loboguerro-Rodríguez, A.M.; Van Etten, J. Directions for climate action in agriculture. Agric. Dev. 2017, 30, 2-3.

22. FAO. Save and Grow: A Policy Maker's Guide to the Sustainable Intensification of Smallholder Crop Production; Food and Agriculture Organization of the United Nations: Rome, Italy, 2011; p. 102.

23. Lipper, L.; Thornton, P.; Campbell, B.M.; Baedeker, T.; Braimoh, A.; Bwalya, M.; Caron, P.; Cattaneo, A.; Garrity, D.; Henry, K.; et al. Climate-smart agriculture for food security. Nat. Clim. Chang. 2014, 4, 1068-1072. [CrossRef]

24. Mkomwa, S.; Kassam, A.H.; Friedrich, T.; Shula, R.K. Conservation agriculture in Africa: An overview. In Conservation Agriculture for Africa. Building Resilient Farming Systems in a Changing Climate; Kassam, A.H., Mkomwa, S., Friedrich, T., Eds.; CAB International: Oxford, UK; Boston, MA, USA, 2017; pp. 1-9.

25. Giller, K.E.; Witter, E.; Corbeels, M.; Tittonell, P. Conservation agriculture and smallholder farming in Africa: The heretics' view. Field Crops Res. 2009, 114, 23-34. [CrossRef]

26. Garrity, D.P. How to make conservation agriculture evergreen. In Conservation Agriculture for Africa. Building Resilient Farming Systems in a Changing Climate; Kassam, A.H., Mkomwa, S., Friedrich, T., Eds.; CAB International: Oxford, UK; Boston, MA, USA, 2017; pp. 167-182.

27. Sims, B.G.; Kienzle, J.; Mkomwa, S.; Friedrich, T.; Kassam, A.H. Mechanization of smallholder conservation in Africa: Contributing resilience to precarious systems. In Conservation Agriculture for Africa. Building Resilient Farming Systems in a Changing Climate; Kassam, A.H., Mkomwa, S., Friedrich, T., Eds.; CAB International: Oxford, UK; Boston, MA, USA, 2017; pp. 183-213. 
28. Baker, C.J. Seeding openers and slot shape. In No-Tillage Seeding in Conservation Agriculture, 2nd ed.; Baker, C.J., Saxton, K.E., Eds.; Food and Agriculture Organization of the United Nations: Rome, Italy; Wallingford, UK; Boston, MA, USA, 2007; pp. 34-59.

29. ACIAR. Fine Tuning the Happy Seeder Technology for Adoption in Northwest India. Australian Centre for International Agricultural Research. Available online: http://aciar.gov.au/project/cse/2006/124 (accessed on 27 March 2017).

30. Sims, B.G. Some advances in mechanization options for conservation agriculture from the fifth world congress of conservation agriculture, Brisbane, Australia, September 2011. Agric. Dev. 2012, 15, 13-15.

31. FAO. Conservation Agriculture. Available online: http://www.fao.org/ag/ca/ (accessed on 27 March 2017).

32. Sims, B. Organic Farming and Agroforestry in the Fens: A visit to Whitehall Farm, Peterborough. 2014. Available online: https://drive.google.com/file/d/0BwyIPGne8KZ-WDdLZX15TGhsQU0/view (accessed on 28 March 2017).

33. Sims, B.G. Small-scale agro-industries for agricultural sector growth: Some practical examples. Agric. Dev. 2012, 16, 10-13.

34. FAO. Agricultural Cooperatives Are Key to Reducing Hunger and Poverty. 2011. Available online: http: / /www.fao.org/news/story/en/item/93816/icode/ (accessed on 30 March 2017).

35. FAO. Addressing the challenges facing agricultural mechanization input supply and farm product processing. In Proceedings of the FAO Workshop held at the CIGR World Congress on Agricultural Engineering, Bonn, Germany, 5-6 September 2006; Sims, B.G., Kienzle, J., Cuevas, R., Wall, G., Eds.; Food and Agriculture Organization of the United Nations: Rome, Italy, 2007; p. 71.

36. FAO. Hire Services by Farmers for Farmers. Diversification Booklet Number 19; Sims, B., Röttger, A., Mkomwa, S., Eds.; Food and Agriculture Organization of the United Nations: Rome, Italy, 2011; p. 83.

37. Houmy, K.; Clarke, L.J.; Ashburner, J.; Kienzle, J. Agricultural mechanization in sub-Saharan Africa: Guidelines for preparing a strategy. Integr. Crop Manag. 2013, 22, 93.

38. Sims, B.; Kienzle, J. Mechanization of conservation agriculture for smallholders: Issues and options for sustainable intensification. Environments 2015, 2, 153-158. [CrossRef]

39. Amanor, K.S.; Chichava, S. South-south cooperation, agribusiness and African agricultural development: Brazil and China in Ghana and Mozambique. World Dev. 2016, 81, 13-23. [CrossRef]

40. Consultative Meeting on Mechanization Strategy: New Models for Sustainable Agricultural Mechanization in Sub-Saharan Africa. Available online: http:/ / africamechanize.act-africa.org/ (accessed on 3 April 2017).

41. Hastedt, A. German machinery rings: Experiences and lesson learnt. In Proceedings of the Consultative Meeting on Mechanization Strategy: New Models for Sustainable Agricultural Mechanization in Sub-Saharan Africa, Nairobi, Kenya, 1-3 December 2016.

42. Herbel, D.; Rocchigiani, M.; Ferrier, C. The role of the social and organisational capital in agricultural cooperatives' development: Practical lessons from the CUMA movement. J. Co-op. Organ. Manag. 2015, 3, 24-31.

43. Nouwogou, K. Promouvoir la mécanisation agricole à travers les coopératives agricoles: Cas de CUMAS au Benin. In Proceedings of the Consultative Meeting on Mechanization Strategy: New Models for Sustainable Agricultural Mechanization in Sub-Saharan Africa, Nairobi, Kenya, 1-3 December 2016.

44. Moreira, J. Sustainable mechanization development strategy options and the role of public-private and private-private partnerships. In Proceedings of the Consultative Meeting on Mechanization Strategy: New Models for Sustainable Agricultural Mechanization in Sub-Saharan Africa, Nairobi, Kenya, 1-3 December 2016.

45. Papastavrou, S. Mechanization strategies from an industrial perspective. In Proceedings of the Consultative Meeting on Mechanization Strategy: New Models for Sustainable Agricultural Mechanization in Sub-Saharan Africa, Nairobi, Kenya, 1-3 December 2016.

46. Mphatso, M. Facilitating small scale farmers' access to conservation agriculture mechanization. In Proceedings of the Consultative Meeting on Mechanization Strategy: New Models for Sustainable Agricultural Mechanization in Sub-Saharan Africa, Nairobi, Kenya, 1-3 December 2016.

47. Ogirinye, I. Private sector driven agricultural mechanization programme (PSDAMP) and GES application strategy of Nigeria. In Proceedings of the Consultative Meeting on Mechanization Strategy: New Models for Sustainable Agricultural Mechanization in Sub-Saharan Africa, Nairobi, Kenya, 1-3 December 2016. 
48. Ströh de Martínez, C.; Feddersen, M.; Speicher, A. Food Security in Sub-Saharan Africa: A Fresh Look on Agricultural Mechanisation; Deutsches Institut für Entwicklungspolitik gGmbH: Bonn, Germany, 2016; p. 171.

49. Cultivating Farms of the Future. Available online: http://blog.agcocorp.com/2015/05/cultivating-farmsof-the-future/ (accessed on 6 April 2017).

50. Moore, M.; AGCO. Personal communication, December 2016.

51. Müller, C. Food security in SSA: A fresh look on agricultural mechanization. In Proceedings of the Consultative Meeting on Mechanization Strategy: New Models for Sustainable Agricultural Mechanization in Sub-Saharan Africa, Nairobi, Kenya, 1-3 December 2016.

52. Starkey, P. Deutsches Zentrum für Entwicklungstechnologien-GATE. In Animal-Drawn Toolcarriers: Perfected yet Rejected: A Cautionary Tale of Development; Deutsche Gesellschaft für Technische Zusammenarbeit (GTZ) GmbH: Wiesbaden, Germany, 1988; p. 161.

53. FAO; ACT. Consultative Meeting on Mechanization Strategy: New Models for Sustainable Agricultural Mechanization in Sub-Saharan Africa; Food and Agriculture Organization of the United Nations (FAO): Rome, Italy; African Conservation Tillage Network: Nairobi, Kenya, 2017; p. 50.

54. United Nations Economic and Social Commission for Asia and the Pacific (ESCAP), CSAM-Centre for Sustainable Agricultural Mechanization. Available online: http:/ /un-csam.org/ (accessed on 11 April 2017).

55. Casão Junior, R.; Guilherme de Araújo, A.; Fuentes Llanillo, R. No-Till Agriculture in Southern Brazil—Factors that Facilitated the Evolution of the System and the Development of the Mechanization of Conservation Farming; Food and Agriculture Organization of the United Nations (FAO): Rome, Italy; Agricultural Research Institute of Paraná State (IAPAR): Paraná, Brazil, 2012; p. 77.

56. Kienzle, J. Sustainable agricultural mechanization. In Proceedings of the Consultative Meeting on Mechanization Strategy: New Models for Sustainable Agricultural Mechanization in Sub-Saharan Africa, Nairobi, Kenya, 1-3 December 2016.

(C) 2017 by the authors. Licensee MDPI, Basel, Switzerland. This article is an open access article distributed under the terms and conditions of the Creative Commons Attribution (CC BY) license (http:/ / creativecommons.org/licenses/by/4.0/). 